\title{
Kisspeptin and Hematologic Parameters as Predictive Biomarkers for First-Trimester Abortions
}

\author{
IIlk Trimester Düşükleri Için Öngörücü Biyobelirteçler Olarak Kisspeptin \\ ve Hematolojik Parametreler
}

\author{
Umit GORKEM $\odot$, Ozgur KAN $\odot$, Mehmet Omer BOSTANCI $\odot$, Deniz TASKIRAN $\odot$, Hasan Ali INAL $\odot$
}

Ethics Committee Approval: This study was approved by Ankara Numune Training and Research Hospital Ethics Committee, 19 August 2015, E-1-562

Conflict of interest: The authors declare that they have no conflict of interest.

Funding: None.

Informed Consent: Informed consents were from the participants of the study.
Cite as: Gorkem U, Kan O, Bostancı MO, Taskiran D, Inal HA. Kisspeptin and hematologic parameters as predictive biomarkers for first-trimester abortions. Medeni Med J. 2021;36:98-105.

\begin{abstract}
Objective: Spontaneous abortion is the most common complication of early pregnancy, affecting up to $20 \%$ of recognized pregnancies. Kisspeptin is predominantly released by placental syncytiotrophoblasts, and regulates their placental invasion into the uterine matrices. We aimed to establish an association of serum kisspeptin levels with pregnancy outcomes during the early gestational stage of the first trimester.

Method: In this prospective study, 90 pregnant women in their 7 to $86 / 7$ gestational weeks were classified into three groups: (i) The control group, consisting of healthy pregnant women $(n=30)$, (ii) the threatened abortion group $(n=30)$, and (iii) the spontaneous abortion group $(n=30)$. The maternal serum samples were analyzed for complete blood count parameters and kisspeptin levels.

Results: There was no statistical difference regarding body mass index (BMI) and gestational age $(p=0.370)$. Regarding detailed obstetric notations, including gravida, parity, abortion, and living children, socioeconomic levels, and employment rates, all study groups were comparable ( $p>0.05$, for all). No significant association was found regarding the biochemical parameters of complete blood count, including neutrophil, lymphocyte, and platelet concentrations, as well as neutrophil-to-lymphocyte ratios (NLR) and platelet-to-lymphocyte ratios $(P L R)(p>0.05$, for all). The median serum kisspeptin levels of the study groups did not differ between the groups $(p=0.153)$. Correlation analysis revealed no significant relationship between serum kisspeptin levels and other study parameters in any study groups ( $p>0.05$, for all)

Conclusions: We found no statistically significant relationship between serum kisspeptin concentrations and pregnancy outcomes in the early gestational stage of the first trimester, and serum kisspeptin concentrations did not seem to be a reliable marker to distinguish abortion status from viable pregnancy.
\end{abstract}

Keywords: Abortion, kisspeptin, neutrophil-to-lymphocyte ratio, platelet-to-lymphocyte ratio

Öz

Amaç: Spontan abortus, erken gebeliğin en sık görülen komplikasyonudur ve tanınan gebeliklerin \% 20'sini etkilemektedir. Kisspeptin, plasental sinsitiyotrofoblastlar tarafindan salınmakta olup rahim matrislerine plasental invazyonu düzenlemektedir. Biz bu çalışmada ilk trimesterin erken gebelik evresindeki gebelik sonuçları ile serum kisspeptin düzeyleri arasında bir ilişki kurmayı amaçladık. Yöntem: Bu prospektif çalışmada, 7-8 6/7 hafta gebelikleri olan doksan gebe toplam üç gruba ayrıldı: (i) sağlıklı gebelerden oluşan kontrol grubu $(n=30)$, (ii) düşük tehdidi grubu $(n=30)$ ve (iii) spontan düşük grubu $(n=30)$. Maternal serum örnekleri, tam kan sayımı parametreleri ve kisspeptin seviyeleri analiz edildi.

Bulgular: Vücut kütle indeksi ve gebelik yaşı açısından istatistiksel olarak fark yoktu ( $p=0.370)$. Gravida, parite, kürtaj ve yaşayan çocuklar, sosyo-ekonomik düzey ve istihdam dahil olmak üzere ayrıntılı obstetrik durumlarla ilgili olarak calıșma grupları arasında fark yoktu (p>0.05). Nötrofil, lenfosit ve trombosit sayılarının yanı sıra nötrofil-lenfosit oranı (NLR) ve trombosit-lenfosit oranı (PLR) dahil olmak üzere tam kan sayımının biyokimyasal parametreleri açısından önemli bir ilişki bulunmadı ( $p>0.05)$. Calışma grupları arasında medyan serum kisspeptin seviyeleri anlamlı farklıık göstermedi $(p=0.153)$. Korelasyon analiz testi tüm çalışma gruplarında kisspeptin ile diğer çalışma parametreleri arasında bir korelasyonun olmadığını gösterdi ( $p>0.05)$.

Sonuç: Bulgularımız, birinci trimesterin erken gebelik evresinde serum kisspeptin konsantrasyonu ile gebelik sonuçları arasında herhangi bir ilişkinin olmadığını ve serum kisspeptin konsantrasyonunun düşük durumunu canlı gebeliklerden ayırt etmek için güvenilir bir belirteç olmadığını göstermiştir.

Anahtar kelimeler: Düşük, kisspeptin, nötrofil-lenfosit oranı, trombosit-lenfosit oranı
Received: 18 February 2021

Accepted: 4 May 2021

Online First: 18 June 2021

Corresponding Author:

H.A. Inal

ORCID: 0000-0002-8361-7908 Konya Training and Research

Hospital, Departmant of

Obstetric and Gynecology, Konya, Turkey

dr.hasanaliinal@yahoo.com

U. Gorkem

ORCID: 0000-0002-0848-9731

Hitit University, Medical

Faculty, Department of

Obstetric and Gynecology,

Corum, Turkey

O. Kan

ORCID: 0000-0003-3994-0094

D. Taskıran

ORCID: 0000-0001-7270-4566

Hitit University Medical

Faculty, Departmant of

Obstetric and Gynecology, Corum, Turkey

M.O. Bostancı

ORCID: 0000-0002-2887-1073

Hitit University Medical Faculty,

Department of Physiology,

Corum, Turkey 


\section{INTRODUCTION}

As a recent popular neuropeptide, kisspeptin has been revealed to mediate feedback of sex steroids and metabolic input on the hypothalamic-pituitarygonadal axis. Kisspeptin, which is encoded by the KISS-1 gene, is expressed in a variety of regions in the brain, especially in the hypothalamus ${ }^{1}$, and is crucial for reproductive functions ${ }^{2}$. The role of extrahypothalamic kisspeptins was demonstrated regarding central and peripheral regulation of different organ systems ${ }^{3,4}$. Kisspeptins and their assumed receptor, KISS-1, were found across numerous locations, including the hippocampus, cerebellum, brain stem, pituitary gland, uterus, ovary, placenta, testicle, adipose tissue, pancreas, liver, and vascular system ${ }^{5-7}$. Apart from these, kisspeptin is predominantly produced by trophoblastic cells and causes placental syncytiotrophoblasts to regulate their invasion into the uterine matrices ${ }^{7,8}$. Kisspeptin levels rise markedly throughout pregnancy in humans, with an approximately 900-fold increase in the first trimester; and thereafter, over 7000-fold in the later stages of gestation and fall precipitously at birth?

Kisspeptin could limit the invasion of primary trophoblast cells and cell lines in vitro, indicating a pivotal role in the regulation of the trophoblastic invasion process ${ }^{6,10}$. Also, kisspeptin can stimulate hormonal production, especially progesterone synthesis in granulosa cells ${ }^{11}$. Presumably, locally produced kisspeptins operate on implantation and placentation processes through autocrine/ paracrine functions and may have a variety of duties in determining favorable pregnancy outcomes ${ }^{12,13}$. Therefore, kisspeptin may contribute to particular crucial processes during pregnancy.

Spontaneous abortion is one of the most common complications of early pregnancy, affecting up to $20 \%$ of recognized pregnancies ${ }^{14,15}$. Threatened miscarriage is reported to occur in approximately one-fifth of pregnancies ${ }^{16}$. However, an estimated $3-16 \%$ of these pregnancies subsequently progress to miscarriage ${ }^{17}$. It is clear that the development of an early screening test to detect patients who has a risk of miscarriage would be beneficial to provide more psychological support and to continue treatment. Although numerous markers have been studied to identify those at risk of subsequent abortion, there is still a lack of consistent findings in the existing literature.

Recently, as the role of inflammatory and/or ischemia markers, complete blood count (CBC) parameters, the neutrophil-to-neutrophil ratios (NLRs) and platelet-to-lymphocyte ratios (PLRs) increased in importance in numerous fields of medicine ${ }^{16-18}$. NLR is regarded as an important marker of the immune response to offending agents, providing a rapid and reliable marker of systemic inflammation and stress ${ }^{18}$. PLR is another parameter considered to increase in thrombotic and inflammatory processes ${ }^{19}$. Hereupon, a variety, and increasing number of investigations related to hematologic markers and early pregnancy outcomes have been cited in the literature ${ }^{9,19}$.

We aimed to establish an association of serum kisspeptin levels with pregnancy outcomes during the early gestational stage of the first trimester. As a secondary aim, the associations of $\mathrm{CBC}$ parameters including NLR and PLR with early pregnancy outcomes were analyzed.

\section{MATERIAL and METHOD}

\section{Study population and design}

The present study had a prospective design and included pregnant women who presented to Hitit University, Medical Faculty, Department of Obstetric and Gynecology, Corum, Turkey, between September 2018 and August 2019. This study was approved by Ankara Numune Training and Research Hospital Ethics Committee (reference number: E-15-562) and conducted in accordance with the Declaration of Helsinki. Written informed consent was obtained from all subjects at the beginning of study. 
Pregnant women who were admitted to the emergency and outpatient departments of the university hospital were included in the study, consecutively. Initially, a detailed demographic and medical history, including age, weight, height, gestational age, reproductive history, delivery mode, socioeconomic level, and employment status, was gathered from each woman. Body mass index (BMI) was calculated by using the women's weight and height recorded at the time of admission. At the first visit, gestational age was determined according to the last menstrual period. Pregnant women with 7 to $86 / 7$ gestational weeks were enrolled in the study.

Spontaneous abortion was defined as the appearance of a gestational sac $\geq 25 \mathrm{~mm}$ on transvaginal ultrasonography without embryonic pole, an embryonic pole $\geq 7 \mathrm{~mm}$ without fetal cardiac activity, inappropriate growth of a gestational sac, lack of fetal embryonic cardiac activity after previously recorded embryonic cardiac activity, or downstream human chorionic gonadotropin (hCG) after admission with vaginal bleeding ${ }^{20}$. Threatened abortion was diagnosed when vaginal bleeding accompanied a closed cervix in early pregnancy and a subsequent ultrasound scan demonstrated fetal cardiac activity ${ }^{15}$. All ultrasound evaluations during follow-up were performed by the same physicians (UG and OK) using a transvaginal 7.5- $\mathrm{mHz}$ probe (Toshiba Xario 100, Toshiba Medical System Co., Nasu, Japan).

The inclusion criteria were accepted as maternal age between 20 and 35 years, patients with a singleton pregnancy between 7 to $86 / 7$ gestational weeks, BMI between 20.0 and $\geq 30.0$ $\mathrm{kg} / \mathrm{m}^{2}$, nonsmokers, and no recent history of trauma during gestation. Patients with multiple pregnancies, a history of recurrent pregnancy loss or gestational hypertensive disorder in prior pregnancies, alcohol consumption, presence of genetic disorder, and medical drug use that might affect fetal surveillance were excluded.
Consequently, all pregnant women who met the inclusion criteria $(n=90)$ were classified into three groups: (i) The control group, consisting of healthy pregnant women $(n=30)$, (ii) the threatened abortion group ( $n=30)$, and (iii) the spontaneous abortion group $(n=30)$.

\section{Specimen collection and assays}

The maternal serum samples were drawn from the antecubital veins using a polypropylene syringe and then collected into $5-\mathrm{mL}$ separator tubes (BD Vacutainer, Becton Dickinson, New Jersey, USA) and hemogram tubes (Isotherm, EDTA.K3, Istanbul, Turkey). To investigate the effect of CBC parameters including concentrations of neutrophils, platelets, and lymphocytes, NLR and PLR, blood samples were analyzed daily using a hematology analyzer (Sysmex XE2100, TOA Medical Electronics, Kobe, Japan). The blood samples for kisspeptin analyses were centrifuged at $1500 \mathrm{~g}$ for four minutes and then collected sera were frozen at $-20^{\circ} \mathrm{C}$ within two hours. The concentrations of kisspeptin in serum samples were measured using an enzyme-linked immunosorbent assay (ELISA) kit (Kisspeptin 54, product no. SEC559Hu, Cloud-Clone Corp, TX, USA). ELISA reagent preparations and protocols were performed as described by the manufacturer. The detection limit of kisspeptin was $24 \mathrm{pg} / \mathrm{mL}$; intra- and inter-assay coefficients of variation were less than $10 \%$.

\section{Statistical Analysis}

The SPSS 15.0 for Windows software package (SPSS, Chicago, IL, USA) was used for statistical analyses of the data. Shapiro-Wilk test was preferred to determine the normality of statistical distribution for continuous variables. One-way analysis of variance (ANOVA) or the Kruskal-Wallis test was used for continuous variables. Categorical data were examined using Fisher's exact test and presented as the number of cases and percentages. Continuous variables were demonstrated as the mean \pm standard deviation (SD) or median and interquartile ranges. Bonferroni correction was 
used to control for type I errors for all possible multiple comparisons. Spearman's correlation test was performed to determine correlations between kisspeptin and other study parameters. A value of $\mathrm{p}<0.05$ was accepted as statistically significance.

The DSS statistical software package for research sample size calculations was used for sample size calculation ${ }^{21}$. Our primary aim of the current study was to analyze the differences in kisspeptin levels among the groups. A minimum of 30 participants in each group would be required to reveal a difference of at least $10 \%$ between the groups, with a power of $80 \%$ at the $5 \%$ significance level. This difference of $10 \%$ was determined both based on a pilot study and our clinical experiments.

\section{RESULTS}

Ninety women were recruited for the study. The comparison of demographic characteristics of all study groups is shown in Table 1 . The mean values of maternal ages were comparable between the study groups $(p=0.370)$. In addition, there was no statistically significant intergroup difference regarding $B M I$ and gestational age $(p=0.080$ and $p=0.564$, respectively). Crown to rump length (CRL) measurements were also found to be statistically similar between the study groups $(p=0.103)$. All study groups were statistically comparable regarding detailed obstetric notations, including gravida, parity, abortion and live births, socioeconomical level and employment, $(p>0.05$, for all).

The comparison of biochemical characteristics of the participant women is presented in Table 2 . No significant association was found regarding hematologic parameters, including neutrophil, lymphocyte, and platelet concentrations ( $p>0.05$, for all). As inflammatory markers, NLR and

Table 1. Comparison of demographic characteristics of pregnant women in all study groups.

\begin{tabular}{|c|c|c|c|c|}
\hline & $\begin{array}{l}\text { Control } \\
\text { Group } \\
(\mathbf{n}=30)\end{array}$ & $\begin{array}{l}\text { Threatened Abortion } \\
\text { Group } \\
(\mathbf{n}=\mathbf{3 0})\end{array}$ & $\begin{array}{l}\text { Spontanous Abortion } \\
\text { Group } \\
(n=30)\end{array}$ & $\mathbf{p}$ \\
\hline aMaternal age (years) & $25.8+3.9$ & $25.5+4.2$ & $27.4+5.8$ & 0.370 \\
\hline${ }^{\mathrm{b} B o d y}$ mass index $\left(\mathrm{kg} / \mathrm{m}^{2}\right)$ & $22.8(21.1-25.7)$ & $25.5(22.2-29.9)$ & $23.9(21.7-28.0)$ & 0.080 \\
\hline 'bestational age (weeks) & $8(7.5-9)$ & $8(7-9)$ & $9(7-9)$ & 0.564 \\
\hline${ }^{\mathrm{b}} \mathrm{CRL}(\mathrm{mm})$ & $15(12.5-20.5)$ & $11.75(9.4-20.5)$ & $11(9.55-19.0)$ & 0.103 \\
\hline 'Gravidity & $2(1-3)$ & $1(1-3)$ & $2(1-3)$ & 0.670 \\
\hline 'Parity & $1(0-2)$ & $0(0-1)$ & $1(0-2)$ & 0.558 \\
\hline${ }^{\mathrm{b}}$ Abortion & $0(0-0)$ & $0(0-0)$ & $0(0-1)$ & 0.788 \\
\hline 'Live births & $1(0-2)$ & $0(0-2)$ & $0(0-1)$ & 0.416 \\
\hline \multicolumn{5}{|l|}{${ }^{\mathrm{C}}$ Delivery mode } \\
\hline - No prior birth & $13(43.4)$ & $16(53.3)$ & $10(33.3)$ & 0.462 \\
\hline • Vaginal & $7(23.3)$ & $6(20.0)$ & $10(33.3)$ & \\
\hline - Cesarean & 7 (23.3) & $8(26.7)$ & $6(20.0)$ & \\
\hline - Both vaginal and cesarean & $3(10.0)$ & $0(0)$ & $4(13.4)$ & \\
\hline \multicolumn{5}{|l|}{ 'Socio-economic level } \\
\hline • Poor & $5(16.7)$ & $3(10.0)$ & $3(10.0)$ & 0.504 \\
\hline - Moderate & $20(66.6)$ & $26(86.7)$ & $25(83.3)$ & \\
\hline • High & $5(16.7)$ & $1(3.3)$ & $2(6.7)$ & \\
\hline \multicolumn{5}{|l|}{ 'Employment } \\
\hline - No & $20(66.7)$ & $24(80.02)$ & $25(83.3)$ & 0.507 \\
\hline - Yes & $10(33.3)$ & $6(20.0)$ & 5 (16.7) & \\
\hline
\end{tabular}

${ }^{a}$ Variables are expressed as mean $\pm S D$.

${ }^{b}$ Variables are expressed as median and inter-quartile range

${ }^{c}$ Categorical values are expressed as number (percentage)

Abbreviation: CRL: Crown-to-rump length.

$p$ values $<0.05$ are accepted as statistically significant. 
Table 2. Comparison of biochemical characteristics of pregnant women in all study groups.

\begin{tabular}{|c|c|c|c|c|}
\hline & $\begin{array}{l}\text { Control } \\
\text { Group } \\
(\mathbf{n}=30)\end{array}$ & $\begin{array}{l}\text { Threatened Abortion } \\
\text { Group } \\
(\mathbf{n}=30)\end{array}$ & $\begin{array}{l}\text { Spontanous Abortion } \\
\text { Group } \\
(\mathbf{n}=\mathbf{3 0})\end{array}$ & $\mathbf{p}$ \\
\hline${ }^{\mathrm{b}} \mathrm{Hb}(\mathrm{g} / \mathrm{dL})$ & $12.7(12.4-13.5)$ & $12.3(11.3-13.1)$ & $12.9(12.4-13.3)$ & 0.231 \\
\hline aNeutrophil concentration $\left(10^{3} / \mu \mathrm{L}\right)$ & $6.6 \pm 2.6$ & $6.1 \pm 1.45$ & $6.0 \pm 1.8$ & 0.527 \\
\hline 'Lymphocyte concentration $\left(10^{3} / \mu \mathrm{L}\right)$ & $1.9(1.7-2.3)$ & $2.3(1.4-3.0)$ & $2.1(1.8-2.7)$ & 0.725 \\
\hline aplatelet concentration $\left(10^{3} / \mu \mathrm{L}\right)$ & $251.4 \pm 59.5$ & $258.4 \pm 88.4$ & $277.9 \pm 72.7$ & 0.521 \\
\hline${ }^{b} N L R$ & $3.2(2.1-4.5)$ & $2.7(2.0-3.8)$ & $3.0(2.0-3.6)$ & 0.838 \\
\hline aPLR & $133.9 \pm 52.2$ & $127.3 \pm 54.8$ & $133.7 \pm 49.7$ & 0.890 \\
\hline${ }^{\mathrm{b}} \mathrm{Kisspeptin}(\mathrm{ng} / \mathrm{mL})$ & $86.7(69.5-112.4)$ & $101.7(85.4-139.4)$ & $102.5(79.5-123.5)$ & 0.153 \\
\hline
\end{tabular}

Abbreviations: Hb: Hemoglobin, NLR: Neutrophil-to-lymphocyte ratio, PLR: Platelet-to-lymphocyte ratio.

${ }^{a}$ Variables are expressed as mean $\pm S D$.

${ }^{b}$ Variables are expressed as median and inter-quartile range

$p$ values $<0.05$ are accepted as statistically significant.

Table 3. Correlation analysis of serum kisspeptin levels with other study parameters.

\begin{tabular}{|c|c|c|c|c|c|c|}
\hline & \multicolumn{2}{|c|}{$\begin{array}{l}\text { Control } \\
\text { Group } \\
(\mathbf{n}=30)\end{array}$} & \multicolumn{2}{|c|}{$\begin{array}{c}\text { Threatened Abortion } \\
\text { Group } \\
(\mathbf{n}=\mathbf{3 0})\end{array}$} & \multicolumn{2}{|c|}{$\begin{array}{c}\text { Spontanous Abortion } \\
\text { Group } \\
(\mathbf{n}=\mathbf{3 0})\end{array}$} \\
\hline & $\mathbf{r}$ & $\mathbf{p}$ & $\mathbf{r}$ & $\mathbf{p}$ & $\mathbf{r}$ & $\mathbf{p}$ \\
\hline Age (years) & 0.154 & 0.463 & -0.074 & 0.731 & -0.238 & 0.357 \\
\hline $\mathrm{BMI}\left(\mathrm{kg} / \mathrm{m}^{2}\right)$ & -0.185 & 0.376 & -0.217 & 0.308 & 0.097 & 0.711 \\
\hline Gestational age (weeks) & -0.077 & 0.714 & -0.114 & 0.595 & -0.051 & 0.845 \\
\hline CRL $(\mathrm{mm})$ & -0.047 & 0.822 & 0.036 & 0.869 & 0.146 & 0.576 \\
\hline NLR & -0.163 & 0.436 & 0.097 & 0.651 & 0.419 & 0.094 \\
\hline PLR & 0.070 & 0.739 & 0.134 & 0.534 & 0.167 & 0.523 \\
\hline
\end{tabular}

Abbreviations: Hb: Hemoglobin, NLR: Neutrophil-to-lymphocyte ratio, PLR: Platelet-to-lymphocyte ratio.

a Variables are expressed as mean $\pm S D$.

${ }^{b}$ Variables are expressed as median and inter-quartile range

$p$ values $<0.05$ are accepted as statistically significant.

PLR were also comparable in all study groups ( $p=0.838$ and $p=0.890$ ). Importantly, the median serum kisspeptin levels of the two study groups did not differ from the control group $(p=0.153)$. Spearman's correlation analysis revealed no significant correlations between serum kisspeptin levels and any other study parameters in all study groups ( $p>0.05$, for all) (Table 3 ).

\section{DISCUSSION}

We mainly focused on evaluating the diagnostic value of serum kisspeptin concentrations in women whose pregnancies would result in miscarriages and in those that would have viable pregnancies in the early gestational stage of the first trimester.
However, maternal kisspeptin levels did not seem to carry a significant impact in predicting abortion risk in pregnant women.

Interestingly, independent studies suggested that serum kisspeptin levels were higher in early placenta than in term placenta ${ }^{10,22}$. The underlying mechanism is thought to be related to aggregated levels of trophoblasts. However, contrarily, a study revealed that plasma kisspeptin levels were lower in various mammals, including sheep, cows, pigs, rabbits, horses, and marmosets, and did not increase during the gestation period ${ }^{23}$. Collectively, it appears to be obscure as to whether the rise in serum kisspeptin levels during gestation is unique to humans ${ }^{24}$. Due to this wide diversity in 
the rise of kisspeptin levels during gestation, the gestational period of our study was limited to $\geq 7$ and $<9$ weeks. In this way, we presumed that the accuracy of kisspeptin in predicting gestational outcomes would be enhanced.

Kiss 1 mRNA expression was detected in adipose tissue. Adipocytes can also be a source of circulating kisspeptin. Kisspeptin may slow the process of lipogenesis and increase lipolysis. Accordingly, kisspeptin could play a major role in the regulation of adipocyte metabolism ${ }^{25,26}$. Based on these data, obesity appears to be an important factor for assessing serum kisspeptin levels. Accordingly, patients with BMIs beyond normal limits were excluded. This point can be considered as a strength of our study, superior to other studies in the present literature.

Kisspeptin concentrations decreased in pregnant women at 16-20 gestational weeks who had placentovascular pathologies, including preeclampsia and intrauterine growth restriction ${ }^{27}$. Cetovic et al. ${ }^{28}$ also reported markedly lower kisspeptin concentrations in pregnant women with type 1 diabetes, gestational diabetes, and gestational hypertensive disorders, despite other studies demonstrating opposing findings ${ }^{29}$. In another study, serum kisspeptin concentrations in the first trimester were lower in pregnant women who subsequently developed small-forgestational-age fetuses ${ }^{30}$. In light of these data, it is possible to hypothesize that abnormal kisspeptin expression from the placenta might be a result of abnormally altered placental function.

In the existing literature, several studies proposed that serum kisspeptin levels showed great accuracy in discriminating abortion from intrauterine pregnancy $^{31}$. In a study performed by Jayasena et al. ${ }^{32}$, circulating kisspeptin concentrations at antenatal booking appointment were lower in women with abortion risk compared those with healthy pregnancies. In addition, Sullivan-Pyke et al. ${ }^{33}$ revealed similar findings in their miscarriage group. Moreover, lower kisspeptin levels were also found in pregnant women diagnosed as having threatened abortion in a study from Turkey ${ }^{23}$. All of these findings suggested that kisspeptin levels might be a promising marker for viability of the fetus in earlier stages of pregnancy. However, we found no such relationship between kisspeptin and favorable perinatal outcomes. Moreover, the gestational ages of the study and control groups were selected in a large range, which may have led to incorrect assessments and comparisons in these studies. BMIs characterized as obesity, as a cause of subclinical inflammation, were excluded from our study. In the study population, we also designated a control group including healthy subjects, a threatened abortion group, and a spontaneous abortion group. As another strength of our study, this kind of classification has not been used in previous studies.

The associations of hematologic markers with abortion status of early pregnancy were published in previous studies. In a study performed by Biyik et al. ${ }^{34}$, NLR and PLR values of a missed abortion group were found to be increased compared with healthy pregnant women. Ata et al. ${ }^{35}$ also noticed that PLR was a significant predictor for early pregnancy loss and threatened miscarriage, whereas NLR was not. In a recent study, researchers demonstrated that decreased PRL and increased NLR were identified in the abortion group ${ }^{36}$. Contrary to these findings, we did not determine any association between $C B C$ parameters and abortion status.

In recent years, several publications demonstrated that serum measurements of kisspeptin failed to discriminate between abortion and ongoing pregnancies and also had poor predictive value in terms of abortion ${ }^{37,38}$. Similarly, we also found that serum kisspeptin was not useful to predict pregnancy outcomes. Also, although limited studies have reported the expression of kisspeptin in the embryo ${ }^{39}$, its expression in the embryo has not been clearly documented. It is glaring that all 
serum kisspeptins are not solely derived from the placenta. Increased kisspeptin levels are derived from the liver as a compensatory mechanism of abnormal glucose metabolism ${ }^{40,41}$. Adipose tissue may be a source of circulating kisspeptin, acting as adipokines or as autocrine/paracrine regulators of adipocyte function ${ }^{25}$. Furthermore, evaluation of kisspeptin levels in humans and rodents using commercially available techniques is considered to be unreliable due to wide variations in assay methods, their ranges of detection, and the uncertainty of kisspeptin forms detected (i.e., $\mathrm{KP} 10$, KP15, and KP54) ${ }^{9,28}$. Kisspeptin is a kind of peptide that may easily metabolize in the bloodstream. The half-life of kisspeptin-54 is approximately 30 minutes; kisspeptin-10 has a half-life of four minutes ${ }^{42}$. The ELISA method to detect kisspeptin levels may not be accurate because it easily detects peptides with similar structure, such as RFamide-related peptides, which are also secreted by the placenta during pregnancy. The conflicting results of these studies may be attributed to these reasons.

The study limitations include the relatively small sample size. Secondly, the blood samples for kisspeptin analyses were not obtained during the early weeks of gestation ( $<6$ weeks) or even in the pre-gestational period. Lastly, our study did not include the obstetric outcomes beyond the second trimester of gestation. In respect of the gestational age of women enrolled in the present study, increase in the diagnostic value of circulating kisspeptin levels was proposed as the pregnancy progressed $^{32,33}$. The most important feature of the present study was that the included patients were examined in three different groups and comparisons between groups were made to determine the distinctive concentrations of kisspeptin.

In summary, our findings did not demonstrate any statistically significant relationship between serum kisspeptin concentrations and pregnancy outcomes in the first trimester of pregnancy, revealing that serum kisspeptin concentrations did not seem to be a reliable marker to distinguish abortion status from viable pregnancy. Therefore, our results need further validation in larger study cohorts to develop an accurate predictive test.

\section{CONCLUSION}

Spontaneous abortion is the most common complication of early pregnancy and can affect $20 \%$ of recognized pregnancies. The development of an early screening test to identify patients who are at risk of miscarriage could be beneficial for providing more psychological support and maintenance of therapy. Our study showed that there was no relationship between serum kisspeptin concentrations and pregnancy outcomes in the first trimester of pregnancy, and serum kisspeptin concentrations do not seem to be a reliable marker to distinguish abortion status from viable pregnancy.

\section{REFERENCES}

1. Kotani $M$, Detheux $M$, Vandenbogaerde $A$, et al. The metastasis suppressor gene KiSS-1 encodes kisspeptins, the natural ligands of the orphan $G$ protein coupled receptor GPR54. J Biol Chem. 2001;276:34631-6. [CrossRef]

2. Reynolds RM, Logie JJ, Roseweir AK, McKnight AJ, Millar RP. A role for kisspeptins in pregnancy: facts and speculations. Reproduction. 2009;138:1-7. [CrossRef]

3. Gorkem U, Togrul C, Arslan E, Sargin Oruc A, Buyukkayaci Duman N. Is there a role for kisspeptin in pathogenesis of polycystic ovary syndrome? Gynecol Endocrinol. 2018;34:157-60. [CrossRef]

4. Comninos AN, Anastasovska J, Sahuri-Arisoylu M, et al. Kisspeptin signaling in the amygdala modulates reproductive hormone secretion. Brain Struct Funct. 2016;221:2035-47. [CrossRef]

5. Uenoyama Y, Pheng V, Tsukamura H, Maeda KI. The roles of kisspeptin revisited: inside and outside the hypothalamus. J Reprod Dev. 2016;62:537-45. [CrossRef]

6. Ohtaki T, Shintani Y, Honda S, et al. Metastasis suppressor gene KiSS-1 encodes peptide ligand of a $G$ proteincoupled receptor. Nature. 2001;411:613-7. [CrossRef]

7. Mead EJ, Maguire JJ, Kuc RE, Davenport AP. Kisspeptins are novel potent vasoconstrictors in humans, with a discrete localisation of their receptor, $\mathrm{G}$ protein-coupled receptor 54, to atherosclerosis-prone vessels. Endocrinology. 2007; 148:140-7. [CrossRef]

8. Matjila M, Millar R, van der Spuy Z, Katz A. The differential expression of Kiss1, MMP9 and angiogenic regulators across the feto-maternal interface of healthy human pregnancies: implications for trophoblast invasion and vessel development. PLoS One. 2013;8:e63574. 
[CrossRef]

9. Horikoshi Y, Matsumoto H, Takatsu Y, et al. Dramatic elevation of plasma metastin concentrations in human pregnancy: metastin as a novel placenta-derived hormone in humans. J Clin Endocrinol Metab. 2003;88:914-9. [CrossRef]

10. Bilban M, Ghaffari-Tabrizi N, Hintermann E, et al. Kisspeptin-10, a KiSS-1/metastin derived decapeptide is a physiological invasion inhibitor of primary human trophoblast. J Cell Sci. 2004;117:1319-28. [CrossRef]

11. Basini G, Grasselli F, Bussolati S, et al. Presence and function of kisspeptin/KISS1R system in swine ovarian follicles. Theriogenology. 2018;115:1-8. [CrossRef]

12. Shahed A, Young KA. Differential ovarian expression of KiSS-1 and GPR-54 during the estrous cycle and photoperiod induced recrudescence in Siberian hamsters (Phodopus sungorus). Mol Reprod Dev. 2009;76:44452. [CrossRef]

13. Babwah AV. Uterine and placental KISS1 regulate pregnancy: what we know and the challenges that lie ahead. Reproduction. 2015;150:R121-8. [CrossRef]

14. Inal ZO, Inal HA. Comparison of four methods of treating ectopic pregnancy: a retrospective cohort study. Geburtshilfe Frauenheilde. 2018;78:70-7. [CrossRef]

15. Ozturk Inal Z, Gorkem U, Inal HA. Effects of preoperative anxiety on postcesarean delivery pain and analgesic consumption: general versus spinal anesthesia. J Matern Fetal Neonatal Med. 2020;33:191-7. [CrossRef]

16. Everett $C$. Incidence and outcome of bleeding before the 20th week of pregnancy: prospective study from general practice. BMJ. 1997;315:32-4. [CrossRef]

17. Inal ZO, Inal HA, Kucukkendirci $H$, Oruc AS. Investigation of cesarean sections at Konya Training and Research Hospital Obstetrics and Gynecology Department between 2010 and 2015. Ginekol Pol. 2017;88:185-90. [CrossRef]

18. Gorkem U, Inal ZO, Inal HA, Bostanci MO. Serum progranulin levels are elevated in infertile women with obesity. Endokrynol Pol. 2018;69:661-6. [CrossRef]

19. Çakıroğlu Y, Vural F, Vural B. The inflammatory markers in polycystic ovary syndrome: association with obesity and IVF outcomes. J Endocrinol Invest. 2016;39:899-907. [CrossRef]

20. Doubilet PM, Benson CB, Bourne T, Blaivas M. Diagnostic criteria for nonviable pregnancy early in the first trimester. N Engl J Med. 2013;369:1443-51. [CrossRef]

21. DSS Research. Researcher's toolkit. Available at: http:// www.dssresearch.com/toolkit/sscalc.

22. Cartwright JE, Williams PJ. Altered placental expression of kisspeptin and its receptor in pre-eclampsia. J Endocrinol. 2012;214:79-85. [CrossRef]

23. Kavvasoglu S, Ozkan ZS, Kumbak B, Simsek M, Ilhan N. Association of kisspeptin-10 levels with abortus imminens: a preliminary study. Arch Gynecol Obstet. 2012;285:649-53. [CrossRef]

24. Hu KL, Zhao H, Yu Y, Li R. Kisspeptin as a potential biomarker throughout pregnancy. Eur J Obstet Gynecol Reprod Biol. 2019;240:261-6. [CrossRef]

25. Wolfe A, Hussain MA. The emerging role(s) for kisspeptin in metabolism in mammals. Front Endocrinol (Lausanne). 2018;24:184. [CrossRef]

26. Dudek M, Ziarniak K, Sliwowska JH. Kisspeptin and metabolism: the brain and beyond. Front Endocrinol (Lausanne). 2018;9:145. [CrossRef]
27. Armstrong RA, Reynolds RM, Leask R, Shearing $\mathrm{CH}$, Calder AA, Riley SC. Decreased serum levels of kisspeptin in early pregnancy are associated with intra-uterine growth restriction and pre-eclampsia. Prenat Diagn. 2009;29:982-5. [CrossRef]

28. Cetkovic A, Miljic D, Ljubic A, et al. Plasma kisspeptin levels in pregnancies with diabetes and hypertensive disease as a potential marker of placental dysfunction and adverse perinatal outcome. Endocr Res. 2012;37:78-88. [CrossRef]

29. Arslan E, Gorkem U, Togrul C. Is there an association between kisspeptin levels and gestational diabetes mellitus? Gynecol Obstet Reprod Med. 2019;26:179-83. [CrossRef]

30. Smets EM, Deurloo KL, Go AT, van Vugt JM, Blankenstein $M A$, Oudejans CB. Decreased plasma levels of metastin in early pregnancy are associated with small for gestational age neonates. Prenat Diagn. 2008;28:299-303. [CrossRef]

31. Savaris RF. Kisspeptin as a biomarker for miscarriage: let's wait! Fertil Steril. 2018;109:67. [CrossRef]

32. Jayasena CN, Abbara A, Izzi-Engbeaya C, et al. Reduced levels of plasma kisspeptin during the antenatal booking visit are associated with increased risk of miscarriage. J Clin Endocrinol Metab. 2014;99:E2652-60. [CrossRef]

33. Sullivan-Pyke C, Haisenleder DJ, Senapati S, et al. Kisspeptin as a new serum biomarker to discriminate miscarriage from viable intrauterine pregnancy. Fertil Steril. 2018;109:137-141.e2. [CrossRef]

34. Biyik I, Albayrak M, Keskin F. Platelet to lymphocyte ratio and neutrophil to lymphocyte ratio in missed abortion. Rev Bras Ginecol Obstet. 2020;42:235-9. [CrossRef]

35. Ata N, Kulhan M, Kulhan NG, Turkler C. Can neutrophillymphocyte and platelet-lymphocyte ratios predict threatened abortion and early pregnancy loss? Ginekol Pol. 2020;91:210-5. [CrossRef]

36. Yildirim FB, Tola EN, Sak S, Cankaya BA. The role of complete blood inflammation markers in the prediction of spontaneous abortion. Pak J Med Sci. 2018;34:1381-5. [CrossRef]

37. Yu H, Liu J, Guo H, Chen C, Han Y, Cui Y. Prognostic value of repeated serum kisspeptin measurements in early first trimester pregnancy: a preliminary study. Reprod Biomed Online. 2019;38:465-71. [CrossRef]

38. Hu KL, Zhang Y, Yang Z, et al. Predictive value of serum kisspeptin concentration at 14 and 21 days after frozen-thawed embryo transfer. Reprod Biomed Online. 2019;39:161-7. [CrossRef]

39. Yan C, Wang H, Boyd DD. KiSS-1 represses 92-kDa type IV collagenase expression by down-regulating NF-kappa $\mathrm{B}$ binding to the promoter as a consequence of kappa alpha- induced block of p65/p50 nuclear translocation. J Biol Chem. 2001;276:1164-72. [CrossRef]

40. Hussain MA, Song WJ, Wolfe A. There is kisspeptinand then there is kisspeptin. Trends Endocrinol Metab. 2015;26: 564-72. [CrossRef]

41. Song WJ, Mondal P, Wolfe A, et al. Glucagon regulates hepatic kisspeptin to impair insulin secretion. Cell Metab. 2014;19:667-81. [CrossRef]

42. d'Anglemont de Tassigny X, Jayasena C, Murphy KG, Dhillo WS, Colledge WH. Mechanistic insights into the more potent effect of KP-54 compared to KP-10 in vivo. PLoS One. 2017;12:e0176821. Erratum in: PLoS One. 2018;13:e0192014. [CrossRef] 